\title{
Editorial
}

\section{Economy and Ecology: Encounters and Interweaving}

\author{
Darko B. Vukovic ${ }^{1,2} *$ (i) and Riad Shams ${ }^{3}$ \\ 1 Graduate School of Economics and Management, Ural Federal University, Yekaterinburg 620002, Russia \\ 2 Geographical Institute "Jovan Cvijić" SASA, Djure Jakšića 9, 11000 Belgrade, Serbia \\ 3 Newcastle Business School, Northumbria University, Sutherland Building, 2 Ellison Pl, \\ Newcastle upon Tyne NE1 8ST, UK; riad.shams@northumbria.ac.uk \\ * Correspondence: vdarko@hotmail.rs
}

Received: 28 October 2019; Accepted: 17 December 2019; Published: 24 December 2019

\begin{abstract}
In this editorial text, we point to the importance and development of disciplines that closely link economic sciences with ecology. Drawing on the most important literature in these fields, we have highlighted the trends that are popular today in both fields (double eco features).
\end{abstract}

Keywords: sustainable development; global eco-trends; green economy; eco-tourism; environmental protection; urban and regional issues; industrial ecology; social responsibility; sustainable tourism; circular economy

Thirty years back to the present, the relationship between economy and ecology has become not only a social issue, but also a political issue. The appearance of global environmental problems as a topic in the 1990s had a major impact on the question of sustainable development in the approach to environmental risk and the issue of the trade-off between economic growth and the environment. Regardless, numerous studies have shown that there is no direct trade-off between economic growth and the environment; yet, this issue is topical and related to the question: What is the best way to preserve the environment alongside the economic growth and urbanization of cities and regions? However, today's governments, companies, and individuals are becoming more aware that the use of technology and the increase in economic capacity should not negatively affect the environment.

As the governments of many countries (predominantly developed) became increasingly interested in environmental issues, we began to meet more terms that are dedicated to the conservation of the environment, rational use of resources, sustainability, and the economic potential of a particular location (region). As a result of this policy, we often encounter terminology such as: Sustainable development, global ecotrends, green economy, ecotourism, environmental protection, regional issues, technological impact on ecology (or new version of industrial ecology), ecopolitical problems, social responsibility, corporate responsibility, urban sustainability, sustainable tourism, circular economy, etc. In other words, the link between biodiversity, economics, and technological advancement exists in almost all socioeconomic forms (Figure 1). Before a more detailed explanation, let us first go back to politics, specifically on the political ecology. 


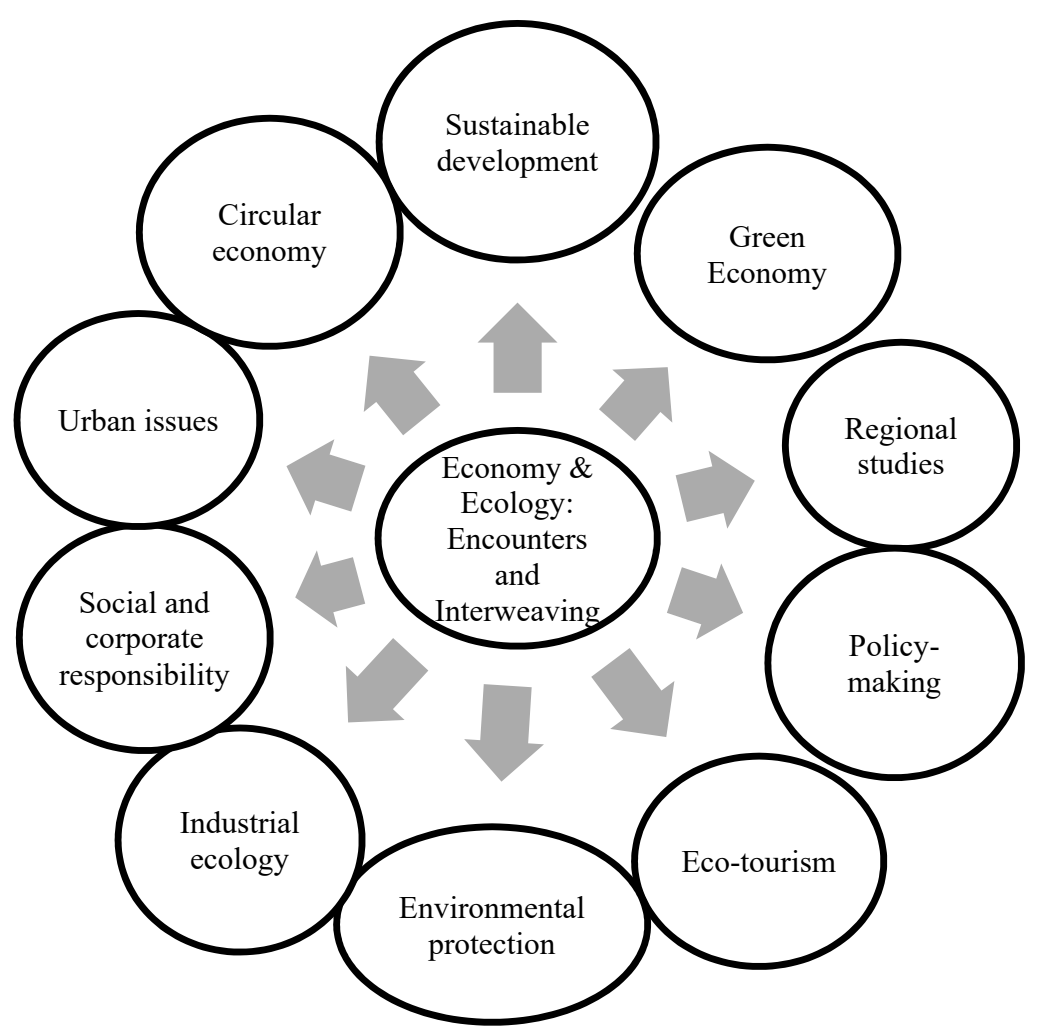

Figure 1. Socioeconomic forms of double eco issue.

The problems of growing pollution, irrational use of rare natural resources, and increasing people's awareness of the importance of ecology and its sustainability have influenced the appearance of political ecology. This branch of science (which is between ecology and political science) should influence economic models to include environmental issues, rational resource consumption, and waste disposal problems. Why is political ecology important? It is important because it represents a political or policy-making view on environmental issues. This is not just about resource efficiency, reduction in energy and greenhouse gas emissions, or waste strategies; it is about sustainability issues and protecting interests of those who are not market-oriented. Public planning, legislation, and implementation of environmental protection strategies with sustainable economic efficiency and productivity, but also with different urban issues, today represent the ecopolitical goals of every modern government.

Another very young (or recent) discipline that deals with the efficiency of scarcity resource use is circular economy. Here, we also have a trade-off between rational uses of natural resources, while ensuring economic growth and job creation [1]. Circular economy appears in various research areas. In the work of Kjaer et al. [2], it was mentioned that circular economy is influenced by environmental economics, industrial ecology, performance economy [3], and blue economy [4]. This is another new (but similar) discipline addressing the issue of waste strategy, recycling, and rational use of natural resources with environmental protection.

Regions, cities, and urban environments are not just a residential space [4,5]. Actually, urban space also has an economic structure [5,6], governance system [4-6], production [5], and service system. Moreover, in the research of Harvey [7], urban space is compared with the financial market, influenced by speculative financial flows and absorbing surplus and impacted by the economic macro crisis. The main driver of urban development is urbanization. According to Liu et al. [8], explained in simple words, urbanization is a complex ecosystem influenced by socioeconomic and environmental (ecological) factors. It is also a vital measure of modernization, industrial improvement, and social development $[9,10]$. However, urbanization has its price, and that price is a negative impact on the environment and ecology. The more the land was used, greater were the effects. There are research studies that deal with this topic, like in the works of Kalnay and Cai [11], Alberti [10], and many others 
today. Urbanization is closely related to the field of regional issues, regional economics, and economic geography. Regional economics and economic geography are important support for the development of environmental issues at a particular location [12-16].

Recently, a very popular new discipline is known as ecological economics. According to Mele et al. [17], Long et al. [18], and Patterson and Glavovic [19], ecological economics combines both doctrines: From one side, it researches the connections between the physical issues and the biological realms, and from the other side, it explores monetary exchange processes on micro, mezzo, and macro levels of economy. This discipline, which is the link between economics and ecology, arose from the need to emphasize their connection, given their social, environmental, political, and sustainable importance nowadays. An even more specific aspect of the ecological economy is the marine economy or maritime, which is the basis of coastal management [17-22]. Marine economy analyzes the natural and economic potential of the region, predicts the ecological consequences, and strives to preserve the environment.

Finally, we must mention the services sector in eco-ecological issues. There has been a lot of attention in both practice (the business, policy-making, various aspects of the social sphere) and science in the last 20 years. Numerous studies address the environmental impact of tourism on ecology; while ecology is one of the most important factors in choosing a tourist destination [23-34]. Ecology in tourism today is not just an issue that must be addressed or protected (as in the productive sectors in the events of pollution or irrational use of resources). It is among the most important characteristics of the attractiveness of a tourist destination. People today choose vacation and leisure destinations that have a natural landscape or high ecological standards [35], which means that investing in ecology is a great opportunity for sustainable economic and social development of a specific destination. The connection between science and practical implications in the relationship between tourism (economy) and ecology has influenced the emergence of many tourism disciplines, such as: Ecotourism, gastro-tourism, adventure tourism, sport tourism, and many similar disciplines.

Author Contributions: Both authors had the same contribution in this paper. All authors have read and agreed to the published version of the manuscript.

Funding: This research received no external funding.

Acknowledgments: The authors are grateful to Ural Federal University, Graduate School of Economics and Management from Yekaterinburg in Russian Federation, and Ministry of Education, Science, and Technological Development in Serbia (III 47007).

Conflicts of Interest: The authors declare no conflict of interest.

\section{References}

1. European Commission. Closing the Loop-An EU Action Plan for the Circular Economy; EC: Brussels, Belgium, 2019. Available online: http://ec.europa.eu/environment/circular-economy/index_en.htm (accessed on 5 October 2019).

2. Kjaer, L.L.; Pigosso, D.C.A.; Niero, M.; Bech, N.M.; McAloone, T.C. Product/Service-Systems for a Circular Economy: The Route to Decoupling Economic Growth from Resource Consumption? J. Ind. Ecol. 2018, 23, 22-35. [CrossRef]

3. Stahel, W.R. The Performance Economy, 2nd ed.; Palgrave MacMillan: London, UK, 2010.

4. Pauli, G.A. The Blue Economy: 10 Years, 100 Innovations, 100 Million Jobs; Paradigm: Taos, NM, USA, 2010.

5. Brenner, N.; Marcuse, P.; Mayer, M. Cities for People, Not for Money; Critical Urban Theory and the Right to the City; Routledge: New York, NY, USA, 2012.

6. Ramos, D. Real Estate Industry as an Urban Growth Machine: A Review of the Political Economy and Political Ecology of Urban Space Production in Mexico City. Sustainability 2019, 11, 1980. [CrossRef]

7. Harvey, D. Rebel Cities. From the Right to the City to the Urban Revolution; Verso: London, UK; New York, NY, USA, 2012.

8. Liu, Y.; Xu, J.; Luo, H. An Integrated Approach to Modelling the Economy-Society-Ecology System in Urbanization Process. Sustainability 2014, 6, 1946-1972. [CrossRef]

9. Morikawa, H. Urbanization and Urban System; Damingtang Press: Tokyo, Japan, 1989. 
10. Alberti, M. The effects of urban patterns on ecosystem function. Int. Reg. Sci. Rev. 2005, 28, 168-192. [CrossRef]

11. Kalnay, E.; Cai, M. Impact of urbanization and land-use change on climate. Nature 2003, 423, 528-531. [CrossRef] [PubMed]

12. Jovanović, A.; Vukovic, D.; Zakić, N. Allocation problems of institutional support for regional development financing in Serbia. Actual Probl. Econ. 2012, 138, 370-380.

13. Vukovic, D.; Markovic, D.; Hanic, A. Snowflake model of regional competitiveness- Evidence from Serbia. Int. Rev. 2016, 1-2, 59-74. [CrossRef]

14. Vukovic, N.; Zalesov, S.; Vukovic, D. Bioenergy Based on Wood Chips as the Development Driver of Non-Urban Forested Areas-The Case Study of Ural Region, Russia. J. Urban Reg. Anal. 2017, 9, $73-85$.

15. Vukovic, D.B.; Radulovic, D.; Markovic, M.; Kochetkov, D.M.; Vlasova, N.Y. Development of a Financial Framework for the National Plan for Regional Development: The Evidence from Serbia. Reg. Econ. 2017, 13, 1314-1328. [CrossRef]

16. Petrovic, M.; Lukic, D.; Radovanovic, M.; Vujko, A.; Gajic, T.; Vukovic, D. The "urban geosites" as an alternative geotourism destination-The evidence from Belgrade. Open Geosci. 2017, 9, 442-456. [CrossRef]

17. Mele, B.H.; Russo, L.; D'Alelio, D. Combining Marine Ecology and Economy to Roadmap the Integrated Coastal Management: A Systematic Literature Review. Sustainability 2019, 11, 4393. [CrossRef]

18. Long, R.D.; Charles, A.; Stephenson, R.L. Key principles of marine ecosystem-based management. Mar. Policy 2015, 57, 53-60. [CrossRef]

19. Patterson, M.G.; Glavovic, B.C. Ecological Economics of the Oceans and Coasts; Edward Elgar Publishing: Cheltenham, UK, 2008.

20. Turner, R.K. Integrating natural and socio-economic science in coastal management. J. Mar. Syst. 2000, 25, 447-460. [CrossRef]

21. Van Assche, K.; Hornidge, A.K.; Schlüter, A.; Vaidianu, N. Governance and the coastal condition: Towards new modes of observation, adaptation and integration. Mar. Policy 2019, 1-10. [CrossRef]

22. Millennium Ecosystem Assessment. Ecosystems and Human Well-Being; Island Press: Washington, DC, USA, 2005; Volume 5.

23. Vukovic, D.B.; Simeunović, I.; Zalesov, S.; Yamashkin, A.A.; Shpak, N. Influence of summer temperatures on basic economic and tourism indicators of the Middle Mediterranean. Therm. Sci. 2015, 19, S361-S370. [CrossRef]

24. Petrović, M.D.; Vujko, A.; Gajić, T.; Vuković, D.; Radovanović, M.; Jovanović, J.M.; Vuković, N. Tourism as an Approach to Sustainable Rural Development in Post-Socialist Countries: A Comparative Study of Serbia and Slovenia. Sustainability 2018, 10, 54. [CrossRef]

25. Vujko, A.; Tretiakova, T.; Dimitrić, D.; Petrović, M.; Radovanović, M.; Vuković, D. Demographic Monitoring and Forecasting Tourists' Arrivals as a Means of Overcoming Seasonality. GeoJ. Tour. Geosites 2018, 22, 524-534. [CrossRef]

26. Petrovic, D.M.; Gelbman, A.; Demirović, D.; Gagic, S.; Vukovic, D. The Examination of the Residents' Activities and Dedication to the Local Community-AnAgritourism Access to the Subject. J. Geogr. Inst. "Jovan Cvijić" SASA 2017, 67, 37-52. [CrossRef]

27. Demirović, D.; Radovanović, M.; Petrović, M.; Cimbaljevic, M.; Vuksanović, N.; Vuković, D.B. Environmental and community stability of a mountain destination: An analysis of residents' perception. Sustainability 2018, 10, 70. [CrossRef]

28. Vujko, A.; Petrović, M.D.; Gostović, D.; Radovanović, M.; Vuković, D. The Role of Natural Resources in the Ecotourism Development-Residents' Perceptions in Subotica (Northern Serbia). Deturope 2018, 10, 112-123.

29. Vujko, A.; Tretiakova, T.N.; Petrović, M.D.; Radovanović, M.; Gajić, T.; Vuković, D. Women's empowerment through self-employment in tourism. Ann. Tour. Res. 2019, 76, 328-330. [CrossRef]

30. Cantino, V.; Giacosa, E.; Alfiero, S.; Shams, S.M.R.; Ferraris, A. Smart tourism business: Sustainability, measurability, awareness, recognition and Technology. Tour. Anal. 2019, 24, 261-263. [CrossRef]

31. Khojastehpour, M.; Shams, S.M.R. Addressing the complexity of stakeholder management in international ecological setting: A CSR approach. J. Bus. Res. 2019. [CrossRef]

32. Shams, S.M.R. Branding destination image: A stakeholder causal scope analysis for internationalization of destinations. Tour. Plan. Dev. 2016, 13, 140-153. [CrossRef] 
33. Shams, S.M.R.; Vrontis, D.; Weber, Y.; Tskouts, E.; Galati, A. (Eds.) Stakeholder Engagement and Sustainability; Routledge: Abingdon, UK, 2019.

34. Bernardi, P.D.; Bertello, A.; Shams, S.M.R. Logics hindering digital transformation in cultural heritage strategic management: An exploratory case study. Tour. Anal. 2019, 24, 315-327. [CrossRef]

35. Chien, M.C. An Empirical Study on the Effect of Attractiveness of Ecotourism Destination on Experiential Value and Revisit Intention. Appl. Ecol. Environ. Res. 2017, 15, 43-53. [CrossRef]

(C) 2019 by the authors. Licensee MDPI, Basel, Switzerland. This article is an open access article distributed under the terms and conditions of the Creative Commons Attribution (CC BY) license (http://creativecommons.org/licenses/by/4.0/). 